\title{
A STUDY ON THE WORK TIME STRUCTURE WHEN SOWING WITH VARIOUS AGGREGATES
}

\author{
Galin Tihanov \\ Department of Agricultural Engineering, Faculty of Agriculture, \\ Trakia University of Stara Zagora, Bulgaria \\ Studentski grad, 6000 Stara Zagora, Bulgaria, e-mail: galin.tihanov@abv.bg
}

\begin{abstract}
One of the factors that influence the working time structure in sowing crops with different aggregates is the utilization of working time. The study dealt with two seed drills for precise and two seed drills for fused sowing. The shift time utilization coefficient in the types of seed drills was determined, which is within the admissible limit: the SZU-3,6 $T=0.86$; for the Horsch Pronto $6 D C$ $T=0.88$ for Gaspardo SP-8 $T=0.92$ and for the Kurt PM-8 seed driller $T=0.85$. It has been established that the field length, its shape and the method of loading the seed drills have an impact on the working time structure when sowing crops with different aggregates. It has been established that in order to exploit the technical capabilities of the sowing aggregate and to achieve higher productivity and good economic performance of the sowing technological operation, the field length of the cultivated area under $600 \mathrm{~m}$ is economically inexpedient.
\end{abstract}

Key words: seed drills, performance, shift time utilization coefficient, field length, modes of movement.

\section{INTRODUCTION}

Sowing is one of the most important technological processes in growing crops. It is also a prerequisite for efficient agricultural production [1]. Depending on the timing and the quality of its performance, crop yields are largely determined [2, 3]. According to Vasilev, negative impact on yield is exerted by both the very early and the late sowing [4]. Also, sowing is a technological operation with increased complexity, because in the process of execution aggregates need adequate technological servicing. Due mainly to the relatively short deadlines for the completion of the operation, conditions are created for using the tractor's nominal drawing power only around 0,85-0,90 [5].

According to Levi, the range within which the total coefficient for utilizing the shift time has to be is $0.75-0.80$ [5]. In order to reach this range, it is necessary, along with the proper assembly of the unit, to take a number of organizational measures, which will reduce idle time to the minimum possible. These measures mainly concern the concentration of aggregates and their regular supply with seeds and mineral fertilizers. As early as the construction of combined seed drills, the volumes of seed and mineral fertilizer hoppers are coordinated in such a way that their loading has still to take place at the same place in the field [5]. According to other authors, sowing aggregates working in the field must be provided with the necessary number of loading vehicles so that their work is not interrupted [6].

The non-working moves of agricultural aggregates include the turns performed by the aggregates in the field, the moves to the machine service areas and the transitions between the fields. The time for making turns is the basis for defining the field machine index and fierld efficiency [7]. Reducing it will have a positive effect on the performance of aggregates. In the course of sowing, the work move has to be selected along the longer side of the field and if possible transversely to the last pre-sowing cultivation. When selecting the direction of

IRITIE Vol. 7, No. 2, 2019 ISSN 1314-8788 (print), ISSN 1314-8796 (online), doi: 10.15547/artte.2019.02.003 


\section{ARTTIE $Y$}

Ipplied Resseirlores in Technics, Technologies and Educration

Journal of the Faculty of Technics and Technologies, Trakia University https://sites.google.com/a/trakia-uni.bg/artte/

the working move, it is planned the seeds in the seedbox of the seed drill to be sufficient for one working move minimum [2].

The most suitable are fields ranging in size from 800 to $1000 \mathrm{~m}$ [2]. With these dimensions, the work move utilization rate almost reaches its maximum value and then increases minimally as field length changes. This also applies to the unit performance.

In order to achieve high productivity in larger farms, it is necessary to build appropriate aggregate groups of grain loaders and seed drills. With this full use of the performance of aggregates has to be achieved. There may be a certain reduction in the productivity of grain loaders, but under no circumstances in that of seed drills. On small agricultural farms higher productivity can be achieved if several farmers co-operate temporarily during sowing to help each other with the available agricultural machinery [2].

The objective of this study is to study the work time structure during sowing with various aggregates and at different field lengths.

\section{MATERIAL AND METHODS}

The survey was conducted in 2018 on the fields during the sowing of three crops: wheat, corn and sunflower. The type of soil is a typical vertisol. Two seed drills for precise sowing and two seed drills for fused sowinf were included in the study. In the table. 1 shows some basic technical characteristics of the seed drills used in the study, and in fig. 1 units in which the study was conducted. Only when sowing the wheat was the field divided into two for the two seeders.

Table 1. Data and basic technical characteristics of seed drills

\begin{tabular}{|c|l|c|c|c|c|}
\hline \multirow{2}{*}{ No } & Types of seed drills & Make and model & Crop & $\begin{array}{c}\text { Working } \\
\text { width, } \\
\text { m }\end{array}$ & $\begin{array}{c}\text { Aggregation } \\
\text { method }\end{array}$ \\
\hline 1 & $\begin{array}{l}\text { Seed drills for } \\
\text { precise sowing }\end{array}$ & Gaspardo SP-8 & Corn & 5,6 & Mounted \\
\cline { 2 - 5 } & Kurt PM-8 & Sunflower & 5,6 & Mounted \\
\hline \multirow{2}{*}{2} & $\begin{array}{l}\text { Seed drills for fused } \\
\text { sowing }\end{array}$ & SZU-3,6 & \multirow{2}{*}{ Wheat } & 3,6 & Trailed \\
\cline { 2 - 3 } \cline { 5 - 6 } & Horsch Pronto 6 DC & 6,0 & Trailed \\
\hline
\end{tabular}

One of the parameters affecting the performance of seed drills is the shift time utilization coefficient $-T$. Through it the efficiency of seed drill utilization can be recorded within the day. By time measurement the duration of the following times was recorded:

$T 1$ - time for seed drill operation, min;

T2 - time for idle moves, min;

T3 - time for loading the seed drill with seeds, min;

T4 - time for idle time due to technical and technological breakdowns, min;

T5 - preparation time, min;

T6 - concluding time, min.

The shift time utilization coefficient within the days was determined by the formula:

$$
\tau=\frac{T 1}{T_{O}}=\frac{T 1}{T 1+T 2+T 3+T 4+T 5+T 6}
$$

where $T 1$ is the actual time when the seed drill is sowing, min; To - total working time, min.

IRTIIE Vol. 7, No. 2, 2019 ISSN 1314-8788 (print), ISSN 1314-8796 (online), doi: 10.15547/artte.2019.02.003 


\section{IRTITE $\vee$}

Ipplied Resseirlores in Technics, Technologies and Educration

Journal of the Faculty of Technics and Technologies, Trakia University https://sites.google.com/a/trakia-uni.bg/artte/

For both types of seed drills - for fused and precise sowing, the impact of the field length on the shift time utilization coefficient at 200,400,600, 800 and $1000 \mathrm{~m}$ working area lengths has been determined by time measurement. The influence of field lengths on wheat sowing was carried out at the "Arpa Dere" block, which is shown in Figure 1a, in the sowing of the maize grasshopper maize (Figure 1b) and in the sowing of the sunflower was carried out on the Ghedeyri block (Figure 1c). The work areas were separated by $200 \mathrm{~m}$, and the time for each of the work areas was measured by chronometry and the coefficient of use of the shift time of the seed drills was determined. The dimensions of the Arpa Dere unit were $1200 \mathrm{~m}$ long and $1420 \mathrm{~m}$ of the Elbe Deer block and $1150 \mathrm{~m}$ of the Ghederry block.

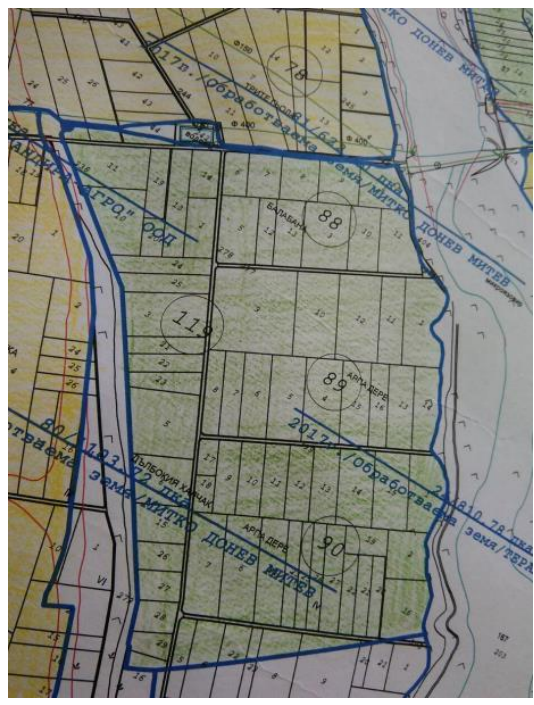

a)

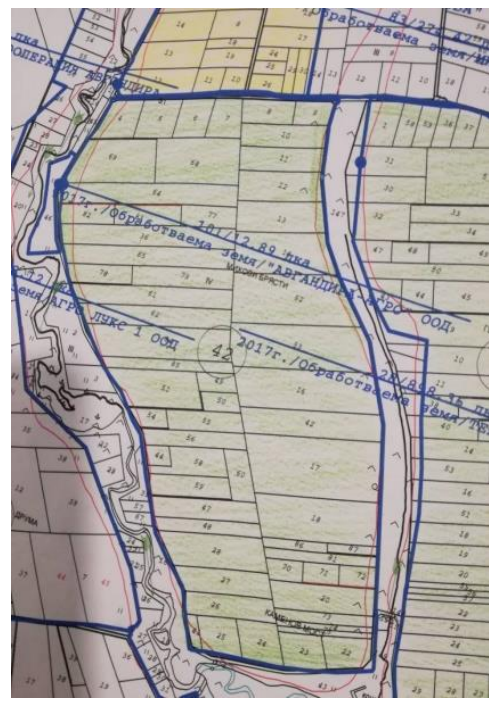

b)

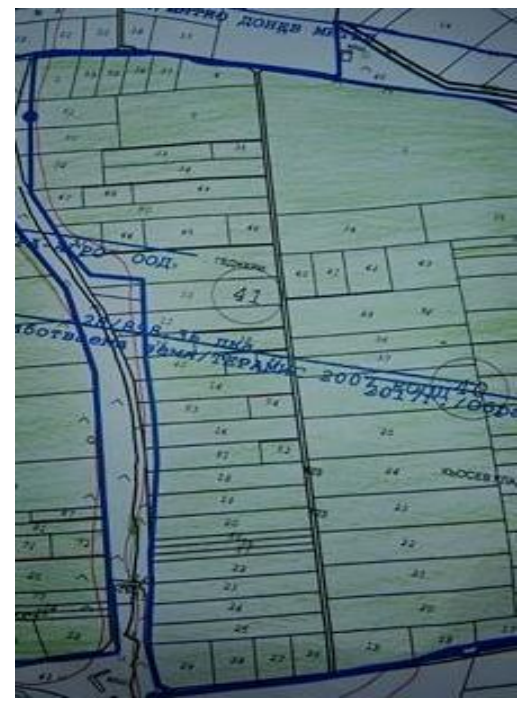

c)

Figure 1. Blocks map:

a) sowing of wheat, b) sowing of corn, c) sowing of sunflower

The mode of movement of the sowing aggregates was a shuttle way with mushroom turns, and the coupling unit was a shuttle with pear-shaped turns. The mode of seed drill loading was at the end of the headland.

\section{RESULTS AND DISCUSSIONS}

Table. 2 shows the results of the duration of the individual times of the coefficient of use of the seed drilling time. The last column of the table determines the coefficient of use of the shift time $\mathrm{T}$ of the seed drills. The results show that the shift time utilization ratio is within the permissible: for the seed drill, the $S Z U-3,6 T=0.86$; for the Horsch Pronto $6 D C T=0.88$ for Gaspardo SP-8 $T=0.92$ and for the Kurt PM-8 seed driller $T=0.85$. Even it can be considered very good because it does not include the time for moving the sowing aggregate to the field and returning it back to the farm.

IRTTIE Vol. 7, No. 2, 2019 ISSN 1314-8788 (print), ISSN 1314-8796 (online), doi: 10.15547/artte.2019.02.003 


\section{IRTITE}

Ipplied Reseertries in Technics, Technologies and Bduration

Journal of the Faculty of Technics and Technologies, Trakia University https://sites.google.com/a/trakia-uni.bg/artte/

Table 2. Duration of the shift time utilization coefficient $t$ of the seed drills in minutes

\begin{tabular}{|c|l|c|c|c|c|c|c|c|c|}
\hline \multirow{2}{*}{ No } & \multirow{2}{*}{$\begin{array}{c}\text { Types of seed } \\
\text { drills }\end{array}$} & \multirow{2}{*}{ Crop } & \multicolumn{6}{|c|}{ Duration, min } & $\begin{array}{c}\text { Shift time } \\
\text { utilization } \\
\text { coefficient }\end{array}$ \\
\cline { 5 - 10 } & & & $T 1$ & $T 2$ & $T 3$ & $T 4$ & $T 5$ & $T 6$ & $T$ \\
\hline 1 & SZU-3,6 & 1333.33 & 133.34 & 32.22 & 21.33 & 24.16 & 15.35 & 0.86 \\
\hline 2 & $\begin{array}{l}\text { Horsch Pronto 6 } \\
\text { DC }\end{array}$ & Wheat & 1455.19 & 125.16 & 29.14 & 18.23 & 18.20 & 14.22 & 0.88 \\
\hline 3 & Gaspardo SP-8 & Corn & 1129.87 & 112.98 & 23.45 & 17.14 & 32.22 & 22.25 & 0.92 \\
\hline 4 & Kurt PM-8 & Sunflower & 1546.20 & 154.62 & 20.50 & 15.33 & 35.4 & 29.17 & 0.85 \\
\hline
\end{tabular}

Taking into account the technical possibilities of the sowing aggregate and the agrotechnical requirements for the sowing technology operation, the influence of the field length on the shift time utilization coefficient $r$ for the two types of seed drills was determined - for fusion and for precise sowing. This was done at different work area lengths of 200, 400, 600, 800 and 1000 $\mathrm{m}$.

Table 3 summarizes the results of the values of the shift time utilization coefficient in sowing crops with fused surface (wheat) and the hoeing crops (corn and sunflower).

Table 3. Shift time utilization coefficient $t$ in seed drills for precise and fused sowing

\begin{tabular}{|c|c|c|c|c|c|c|c|}
\hline \multirow{2}{*}{ Types of seed drills } & \multirow[b]{2}{*}{ Make and model } & \multirow{2}{*}{$\begin{array}{c}\text { Working } \\
\text { width, } \\
B, \mathrm{~m}\end{array}$} & \multicolumn{5}{|c|}{$\begin{array}{c}\text { Field length, } \\
L, \mathrm{~m}\end{array}$} \\
\hline & & & 200 & 400 & 600 & 800 & 1000 \\
\hline \multirow{2}{*}{$\begin{array}{l}\text { Seed drills for precise } \\
\text { sowing }\end{array}$} & Gaspardo SP-8 & 5,6 & 0,33 & 0,52 & 0,63 & 0,70 & 0,74 \\
\hline & Kurt PM-8 & 5,6 & 0,51 & 0,69 & 0,77 & 0,82 & 0,85 \\
\hline \multirow{2}{*}{$\begin{array}{l}\text { Seed drills for fused } \\
\text { sowing }\end{array}$} & SZU-3,6 & 3,6 & 0,19 & 0,36 & 0,47 & 0,55 & 0,61 \\
\hline & $\begin{array}{l}\text { Horsch Pronto } \\
6 \mathrm{DC}\end{array}$ & 6,0 & 0,43 & 0,62 & 0,71 & 0,77 & 0,81 \\
\hline
\end{tabular}

In Figure 2 the relationship between the shift time utilization coefficient and the field length when sowing spring crops $T=f(L)$ has been constructed. It shows that the shift time utilization coefficient for the Gaspardo $S P-8$ seed drill is lower than that of the Kurt PM-8 seed drill. Since both seed drills had the same working width $(B=5.6 \mathrm{~m})$, the cause for this was that the shape of the field at the Gaspardo SP-8 seed drill was irregular. This, in turn, has led to a different number of seedbox seedlings because we have different crops (corn and sunflower) and different sowing norms. Also, the shape of the field did not change the number of turns, but their length. For that reason, the speed of the headland, its type and its length was influenced by its influence.

Figure 3 outlines the dependency between the shift time utilization coefficient and the field length when sowing autumn crops (wheat) $T=f(L)$. Figure 3 shows that there is huge difference between both seed drills, i.e. in the Horsch Pronto $6 D C$ seed drill it is higher that the SZU-3,6 drill. This was due to three reasons. The first reason is the work width of the seed drills $(6,0 \mathrm{~m}$ vs. 3,60 m). The second reason was the fact that the $S Z U-3,6$ had smaller seed hopper and was loaded more frequently, while the third one was the shape of the fields. Also, sowing aggregates have a different kinematic length, which affects the length of the curve.

IRTIIE Vol. 7, No. 2, 2019 ISSN 1314-8788 (print), ISSN 1314-8796 (online), doi: 10.15547/artte.2019.02.003 




Figure 2.

Effect of the field length when sowing spring crops on the shift time utilization coefficient

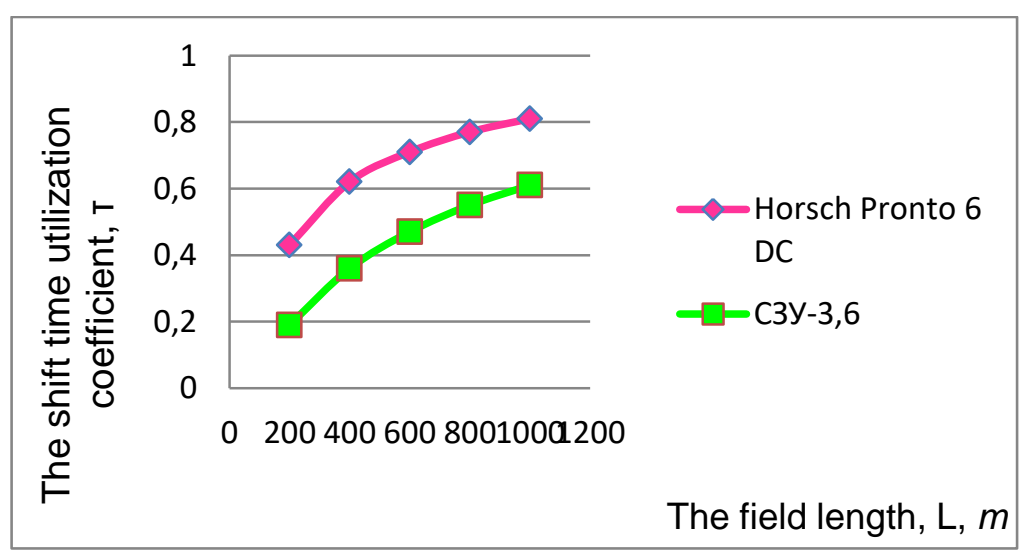

Figure 3.

Effect of the field length when sowing autumn crops on the shift time utilization coefficient

\section{CONCLUSIONS}

The shift time utilization coefficient in sowing is within the permissible: for the seed drill, the SZU-3,6 т = 0.86; for the Horsch Pronto $6 D C \mathrm{~T}=0.88$ for Gaspardo SP-8 $\mathrm{T}=0.92$ and for the Kurt $P M-8$ seed driller $\mathrm{T}=0.85$ since it does not include the time for moving the sowing aggregate to the field and returning it back to the farm.

It has been established that the field length, its shape and the mode of loading the seed drills have an impact on the working time structure when sowing crops with different aggregates. In order to exploit the technical capabilities of the sowing aggregate and to achieve higher productivity and good economic parameters of the sowing technological operation, field length of the cultivated area below $600 \mathrm{~m}$ is economically inexpedient.

IRTIIE Vol. 7, No. 2, 2019 ISSN 1314-8788 (print), ISSN 1314-8796 (online), doi: 10.15547/artte.2019.02.003 


\section{IRTTL}

Ipplied Researl'ches in Technics, Technologies ind Bduration

Journal of the Faculty of Technics and Technologies, Trakia University htps://sites.google.com/a/trakia-uni.bg/artte/

\section{REFERENCES}

[1] Mitev G. (2017). Substantiating technological machines sets for hoe-farming under conditions of drought and water deficit. Dissertation paper for scquiring scientific degree "Doctor of Science”, Ruse University „Angel Kanchev“, Ruse, p. 380.

[2] Kolev K. (1999). Operation of the machine-tractor fleet. Dionis, Sofia, p. 172.

[3] Hristov H. (2009). Analysis of seed drills for precise sowing of hoe-farmed and vegetable crops. Scientific papers of Ruse University, Vol. 48, Series 1.1, pp. 50-55.

[4] Vasilev K. (1987). Industrial technologies in Agriculture. Higher Technical School "Angel Kanchev", Ruse, p. 61.

[5] Levi S. A. (1975). Operation of the machine tractor and car fleet. Sofia, p. 311.

[6] Mandradzhiev S. et al. (1993). Agricultural machinery II part. Hristo G. Danov Publishing House, Plovdiv, p. 272.

[7] Shamshiri R., Ehsani R., Maja J. M. \& Roka, F. M. (2013). Determining machine efficiency parameters for a citrus canopy shaker using yield monitor data. Applied Engineering in Agriculture, 29 (1), pp. 33-41.

IRTTIE Vol. 7, No. 2, 2019 ISSN 1314-8788 (print), ISSN 1314-8796 (online), doi: 10.15547/artte.2019.02.003 